\title{
Nutritional Habits' Review of Amateur and Professional Football Players
}

\author{
Ahmet ÇÖNDÜ ${ }^{1}$, Orhan ŞENER ${ }^{2}$,Fatma Nur TÜRKOĞLU ${ }^{3}$ \\ ${ }^{1}$ Selçuk Üniversitesi, Spor Bilimleri Fakültesi, Beden Eğitimi ve Spor Ĕ̆itimi Anabilim Dalı, Konya, TÜRKİYE \\ ${ }^{2}$ Selçuk Üniversitesi, Spor Bilimleri Fakültesi Beden Eğitimi ve Spor Bölümü Sporda Psikososyal Alanlar Anabilim Dall, Konya, TÜRKIYE. \\ ${ }^{3}$ KTO Karatay Üniversitesi, Tıp Fakültesi, Anatomi Anabilim Dalı, Konya, TÜRKİYE. \\ Address Correspondence to Arş. Gör. Fatma Nur Türkoğlu; \\ Akabe Mahallesi, Alaaddin Kap Cd. No:130 D: No:130, 42020 Karatay/Konya; fatmanur.dursun@karatay.edu.tr; 05423864279
}

\begin{abstract}
The aim of our study is to investigate the dietary habits of amateur and professional football players and their differences. A hundred football players actively playing football during the 2013-2014 football season in 2nd League A Category, 2nd League B Category, 3rd League, 1st Amateur and 2nd Amateur Leagues participated in our study. A questionnaire that consists of 17 personal information and nutritional habits questions was developed based on the literature and was filled out by the players to determine their nutritional habits. There were statistically significant differences between the groups at $\mathrm{p}<0.01$ level across their education level on nutrition issues, number of meals, alcohol and cigarette use, daily fluid intake, pre-game fluid intake, pre-game foods consumed, liquids and food consumed outside of three regular meals, late-time meals, regular supplementary products and last food before games. There were statistically significant differences between the groups at $\mathrm{p}<0.05$ level across information resource on nutrition issues, skipped meals, fluid intake during training, late time meals, attention to expiration dates while shopping.In conclusion, consistent with previous studies in the literature it is found that amateur and professional football players don't have good nutrition information and habits. Clubs, coaches and athletes looking for success on a national and international level should consult and collaborate with a nutritionist. We believe that it will be very useful to train athletes and coaches, with seminars, courses, panels, etc. and to have an expert dietitian in sports clubs, and to emphasize the importance of this issue in written and visual media.
\end{abstract}

Key words:Football Players, Sports Nutrition, Amateur Football Player, Professional Football Player, Nutrition Habits.

\section{INTRODUCTION}

Nutrition is the use of the necessary elements in the body to grow, develop, and live healthy and productive for a long time (11).

Athlete nutrition is an issue that athletes and trainers still do not pay enough attention to. Because, their attention is focused on the elements which will improve their training and performance in very short way. However, nutrition is one of the most important factors determining the athlete's performance in addition to genetic structure and proper training. In recent years, the importance of nutrition in the success of athletes has started to be understood gradually (21).

There is a direct proportion between athletes' nutritional habits and performance. Success can be achieved by making good use of nutrition and energy balancing in the sports done both for health and the amateur and professional sports. Today, nutrition in sports, as a separate science, attracts the attention of every athlete. In fact, athlete nutrition directly shows parallelism with the endless development of science thoroughly. The athletes and trainers' knowing the importance of the nutrition-related information and their implementation is great $(3,21)$. When making a nutrition plan, it is necessary to pay attention as it were a training plan. In the nutritional plan and diet of the athletes, nutritional contents and energy values should be balanced (16).

Upper The importance of nutrition in sports and the relationship between the workout performance and nutrition has been determined by researches carried out. Although there is no "magical formula" to improve performance in 
terms of nutrition in sport, which is considered as a struggle, the nutrition of athletes shows some characteristics and reveals the importance of nutrition (30).

\section{MATERIAL \& METHOD}

The teams playing in different leagues were determined as three teams according to random method. A total of 100 football players - 50 amateur and 50 professional who actively played football in 6 different league categories in the 2013-2014 football season constituted the group of subjects in the research.

In order to determine the nutritional habits of the research, a questionnaire which was used in the scientific studies before $(10,12,13,18,29,35)$ and a questionnaire consisting of 17 personal information and nutrition habits which were developed by taking the opinions of experts was used. First of all, the subjects were give explanations about the questionnaire; the questionnaires were distributed to the athletes directly or through the managers of the athletes, and were collected in the same way by controlling after being completed.

Subjects were warned to provide careful and reliable information to the questions. Statistical calculations were made in SPSS (version 1.4) program.

\section{RESULTS}

The mean age of the professional football players participating in the study was $24.6 \pm 3.8$ years, and the mean age of the amateur players was $22.5 \pm$ 3.8 years; body weight of professional footballers was found to be $72.9 \pm 4.4 \mathrm{~kg}$ and body weight of amateur players was $70.4 \pm 4.5 \mathrm{~kg}$. $52.5 \%$ of professional footballers are high school and equivalent schools graduates and $47.1 \%$ are undergraduates; $51.2 \%$ of amateur football players are of high school and equivalent education level.

When asked about the adequacy of their knowledge about athlete nutrition, professional footballers significantly found themselves more efficient than amateurs $(\mathrm{p}<0.001)$ (Table 1).

$30 \%$ of professionals showed their trainers, $20 \%$ written and visual media, $12 \%$ nutrition books as a source of information on nutrition; $48 \%$ of amateurs showed written and visual media, $28 \%$ nutrition books and $24 \%$ their trainers. While the professionals showed their trainers as a source of information at a significant level compared to the amateurs among the groups, the amateurs showed the written and visual media $(\mathrm{p}<0.05)$.

Amateur footballers said that they skipped significantly more meals than professionals $(p<0.001)$ (Table 1). While breakfast is the most common skipped meal for professional footballers, it is lunch for amateurs.

No significant difference was observed between amateurs and professional footballers in alcohol and smoking $(\mathrm{p}>0.001)$ (Table 1).

While there was no significant difference between amateurs and professional football players in the amount of fluid consumed during training, it was seen that amateurs consumed less liquid in one day compared to professionals $(\mathrm{p}<0.05)$ (Table 1$)$.

When asked about the food consumed by footballers before the competition, $40 \%$ of professional football players stated that they preferred protein-content, $30 \%$ carbohydratecontent, $18 \%$ vitamin-content drinks; and $46 \%$ of amateurs preferred protein-content, $32 \%$ vitamincontent, $18 \%$ carbohydrate-content drinks. While amateurs consumed significantly more protein and vitamin-containing foods than professionals, it was observed that they consumed significantly less carbohydrate and fat-containing foods $(\mathrm{p}<0.001)$.

When asked about the drinks consumed out of the meals, $42 \%$ of the professional footballers stated that they consumed fruit juice, $28 \%$ water, $20 \%$ coke, $10 \%$ tea and coffee; and $30 \%$ of amateur football players consumed fruit juice, $24 \%$ water, $18 \%$ tea and coffee, and $28 \%$ coke more often. Amateurs are observed to consume significantly more coke, tea and coffee, and professionals consumed significantly more juice

and water $(\mathrm{p}<0.001)$.

When asked about the consumed appetizers out of the meals, $44 \%$ of professional footballers were seen to consume fruit, $26 \%$ were toast and $22 \%$ were biscuits, $8 \%$ were chocolate; and $36 \%$ of amateur football players consumed chocolate, $28 \%$ fruit, $18 \%$ toast and $14 \%$ were biscuits. Professionals were seen to consume significantly more fruit and toast than amateurs and amateurs consumed more chocolate $(\mathrm{p}<0,001)$. 
Amateur footballers were found to have significantly more late-evening meals than professionals $(\mathrm{p}<0.05)$ (Table 1$)$.

Professional footballers are more careful than amateurs in paying attention to the expiration dates of foodstuffs in shopping $(\mathrm{p}<0.05)($ Table 1$)$.

When supplementary products (vitamins, minerals, carbohydrates, amino acid tablets, etc.) used regularly by football players were asked, it was seen that professional footballers used significantly more products than amateur football players $(\mathrm{p}<0.001)$ (Table 1).

When asked how many hours ago they consumed the last meal before the competition, $68 \%$ of professional footballers answered that they had 3-4 hours before, $32 \% 1-2$ hours; and $56 \%$ of amateur footballers had 1-2 hours before, 44\% 3-4 hours. Professionals eat their last meal significantly before the competition compared to amateurs $(\mathrm{p}<0.001)$.

It was seen that professional football players thought that they had enough nutrition compared to amateurs $(\mathrm{p}<0.001)($ Table 1$)$.

When asked how many meals they consume per day, $56 \%$ of professional footballers answered that they have $3-4$ meals, $28 \%$ have 5 meals and more, 16\% 1-2 meals; and $60 \%$ of amateur footballers have 3-4 meals, 26\% 1-2 meals, $14 \%$ gave 5 meals and more. It was seen that professional footballers significantly had more meals than amateurs $(\mathrm{p}<0.001)$.

Table 1. Some questions asked to players and answers received.

\begin{tabular}{|c|c|c|c|c|c|c|c|c|c|}
\hline \multirow[t]{2}{*}{ Questions } & & \multicolumn{4}{|c|}{ Amateurs } & \multicolumn{4}{|c|}{ Professionals } \\
\hline & & Yes & No & No idea & Total & Yes & No & No idea & Total \\
\hline \multirow{2}{*}{$\begin{array}{l}\text { Do you find your knowledge on } \\
\text { athlete nutrition sufficient? }(\mathrm{p}<0.001)\end{array}$} & $\mathrm{N}$ & 23 & 16 & 11 & 50 & 28 & 14 & 8 & 50 \\
\hline & $\%$ & 46 & 32 & 22 & 100 & 46 & 28 & 16 & 100 \\
\hline \multirow[t]{2}{*}{ Do you skip meals? $(p<0.001)$} & $\mathrm{N}$ & 36 & 14 & & 50 & 21 & 29 & & 50 \\
\hline & $\%$ & 72 & 28 & & 100 & 42 & 58 & & 100 \\
\hline \multirow[t]{2}{*}{ Do you drink alcohol? $(\mathrm{p}>0.001)$} & $\mathrm{N}$ & 24 & 26 & & 50 & 27 & 23 & & 50 \\
\hline & $\%$ & 48 & 52 & & 100 & 54 & 46 & & 100 \\
\hline \multirow[t]{2}{*}{ Do you smoke? $(p>0.001)$} & $\mathrm{N}$ & 24 & 26 & & 50 & 23 & 27 & & 50 \\
\hline & $\%$ & 48 & 52 & & 100 & 46 & 54 & & 100 \\
\hline \multirow{2}{*}{$\begin{array}{l}\text { Do you take care of fluid intake } \\
\text { during training? }(p<0.001)\end{array}$} & $\mathrm{N}$ & 39 & 11 & & 50 & 42 & 8 & & 50 \\
\hline & $\%$ & 78 & 22 & & 100 & 84 & 16 & & 100 \\
\hline \multirow{2}{*}{$\begin{array}{l}\text { Do you think you have adequate } \\
\text { nutrition? }(\mathrm{p}<0.001)\end{array}$} & $\mathrm{N}$ & 22 & 28 & & 50 & 35 & 15 & & 50 \\
\hline & $\%$ & 44 & 56 & & 100 & 70 & 30 & & 100 \\
\hline \multirow{2}{*}{$\begin{array}{l}\text { Do you eat late in the evening? } \\
(\mathrm{p}<0.05)\end{array}$} & $\mathrm{N}$ & 31 & 19 & & 50 & 21 & 29 & & 50 \\
\hline & $\%$ & 62 & 38 & & 100 & 42 & 58 & & 100 \\
\hline \multirow{2}{*}{$\begin{array}{l}\text { Do you pay attention to the } \\
\text { expiration date of the food you take? } \\
(\mathrm{p}<0.05)\end{array}$} & $\mathrm{N}$ & 29 & 21 & & 50 & 32 & 18 & & 50 \\
\hline & $\%$ & 58 & 42 & & 100 & 64 & 36 & & 100 \\
\hline \multirow{2}{*}{$\begin{array}{l}\text { Do you regularly take supplementary } \\
\text { product supplements? }(\mathrm{p}<0.001)\end{array}$} & $\mathrm{N}$ & 25 & 25 & & 50 & 40 & 10 & & 50 \\
\hline & $\%$ & 50 & 50 & & 100 & 80 & 20 & & 100 \\
\hline
\end{tabular}

\section{DISCUSSION}

The aim of this study was to investigate the differences in nutritional habits of football players according to their status as amateur and professional footballer. Athlete nutrition is an area which studies nutrition science under the scope of "exercisenutrition" interaction and whose importance has been increasing for the last 25 years.

The elite athletes enforcing the extreme points of the human genetic pool and pushing the physically possible training limits are a good model for demonstrating the relationship between nutrition and performance. Proper nutrition does not give a non-elite athlete the chance to become a world-class player. However, with elite athletes, where training and genetic conditions are similar and competition is experienced at a high level, nutrition may be the only element to gain fitness (8). It is the only way that the athlete develops his body, protects his health and achieves high sporting 
performance through balanced, regular and appropriate nutrition to the purpose (33).

The mean age of the professional football players participating in the study was found to be $24.6 \pm 3.8$ years, the mean age of the amateur players was $23.2 \pm 3.8$ years; and the body weights of professional footballers were found to be $72.9 \pm$ $4.4 \mathrm{~kg}$ and the body weights of amateur players were $73.1 \pm 4.5 \mathrm{~kg}$. Amateur and professional footballers are seen to have high school and equivalent school and undergraduate level education in general. Income levels of professional footballers were found to be much higher than amateurs. In the study conducted by Göral et al. (18), $70.8 \%$ of amateur footballers are seen to have high school and equivalent school, $16.7 \%$ of undergraduate, $12.5 \%$ of primary school education level; and according to another study, $67.5 \%$ of football players have high school, $25 \%$ have undergraduate and $7.5 \%$ have primary education level (29).

When Pulur and Cicioglu (31) stated in their study that a large portion such as $54 \%$ of the athletes are knowledgeable about athletes nutrition; and Atay et al (6) stated in their study that $73.7 \%$ of football players have good and very good knowledge about nutrition and $26.2 \%$ of them have low and medium level knowledge about nutrition. In another study conducted by Abood et al. (1), nutritional information of football players was found to be insufficient. In another study, they examined socioeconomic status, nutritional information and habits of 1455 athletes. At the end of the study, it was found out that athletes have nutritional problems. This results in the lack of information about nutrition $(17,35)$. In his study of Öztürk (29), it was found that professionals generally fed more regularly than amateur players. It was found that the majority of the players (51\%) who participated in our study thought that their knowledge about athlete nutrition was sufficient.

According to Sivrikaya (34), $76.6 \%$ of the athletes and according to Sürücüoglu et al (36), $38.3 \%$ of the athletes showed their trainers as a source of information about nutrition. In the study conducted by Senel et al. (39), $42.5 \%$ of the athletes show their trainers as sources of information, and $25.8 \%$ show books-magazines and radio-television. In our study, it was found out that $42 \%$ of all football players received nutritional information from their trainers. This shows that trainers have an important place on athletes in nutrition knowledge.
However, in another study on the nutritional attitudes of the trainers, while the rate of those who received information from the seminars on athlete nutrition was $24.3 \%$, the fact that the trainers who did not receive information was $75.7 \%$ can be expressed as a thought-provoking result (10).

However, in some studies conducted in the literature $(10,40)$, the nutritional knowledge level of the trainers was not found at the desired level. In a study in which the nutritional information of the trainers was measured in the teams, the trainers answered $55.6 \%$ of all information questions correctly. It was concluded that their trainers were not ready enough to give nutrition advice to athletes and should benefit from further nutrition training (41).

Şanlıer and Arıkan (38) stated that $48.1 \%$ of the athletes skipped meals and the skipped meal was generally (51.4\%) breakfast. Bulduk et al (14) stated that $36.8 \%$ of athletes skipped meals, $47 \%$ of them skipped meals in the morning, $46 \%$ of them skipped lunch and 7\% in the evening; and Arıkan and Şanlier (4) reported that $58.6 \%$ of these skipped meals were breakfast and $41.4 \%$ were lunch. In our study, while most of the amateur football players skipped one of the daily meals $(72 \%)$, the majority of professional footballers did not skip meals (58\%); $41 \%$ of those who say that they skipped meals were found to skip breakfast meals, $44 \%$ of them skipped lunch. Our data are similar to the studies in the literature.

In a study Atamtürk et al. (5) conducted on 232 footballers in Northern Cyprus, 55.2\% of footballers smokes, 52.4\% drinks alcohol; according to Akil's (2) study, $43.2 \%$ of athletes drink alcohol and $27 \%$ smokes cigarettes; according to Bilgiç et al. (12), $29.4 \%$ of athletes smoke and $33.3 \%$ smokes 15 or more cigarettes per day. In our study, suitable results were observed with the ones in the literature and it was observed that the harmful habits of football players such as alcohol (51\%) and cigarettes $(47 \%)$ were common.

In a study conducted by Javandel and Berahmandpour (24), they stated that extra fluid should be taken on the match day breakfast, lunch and 10-15 minutes before the match. Bilgic et al. (12) reported that $88.2 \%$ of athletes felt thirsty after the competition and $84.3 \%$ consumed 0.5 liters less liquid before the competition. According to Özmerdivenli and Karacabey's (28) study, $12 \%$ of volleyball players and $24 \%$ of basketball players emphasize that it is important to take water that has 
such important tasks after training and match. It can be understood from this that a large number of athletes consider the task of water only as quenching. However, water is the most important nutrient that can affect the athlete's performance positively or negatively in a short time. In our study, although the majority of the players (81\%) stated that they paid attention to fluid intake, it was found that their fluid consumption was inadequate, similar to other studies in the literature.

Hickner et al. (23) recommend that athletes have a more advanced ability to store carbohydrates after exercise, and athletes should be given foods food containing a high glycemic index. In our study, it was determined that most of the professional football players prefer carbohydrate-containing foods as pre-competition food, mineral and vitamin supplements which are thought to be energyenhancing among football players are used quite regularly and with the majority of their own will.

For years, athletes believe that supplementary protein intake increases muscle performance, while nutritionists and physiologists have argued whether supplementary protein is required for optimal athlete performance or not (Gürsoy 22). In a study conducted by Ayca and Ciloglu (7) on football players, $37 \%$ out of 127 football players use protein powders, amino acids and sports drinks. Akil (2) reported that $76.4 \%$ of the athletes participating in the research use energy enhancers and $6.6 \%$ do not use and the rest of the athletes benefit rarely. Douglas and Douglas (15) found out in a study that athletes used high levels of vitamins and minerals (58\%). According to Bozkurt's (13) study, $52.1 \%$ of the athletes do not use foods that they consider as energy enhancers while $44.3 \%$ of athletes do use. Öztürk (29) found that the rate of use of products such as vitamin-mineral preparation, energy drink, sports drink among amateurs was lower than that of professionals. Massad et al. (26) found out in a study that $41.7 \%$ of athletes used vitamin and mineral supplements. According to the study of Güler et al. (19), $25.4 \%$ of the athletes used supplementary sports nutrition and $74.6 \%$ did not use it; Swirzinski et al. (37) found that $31 \%$ of football players use supplementary sports nutrition. In our study, it was seen that the rate of supporting product use in professional football players $(80 \%)$ was much higher than amateurs $(50 \%)$.
In Leblanc et al. (25) stated that the number of meals was insufficient in their study conducted on young French football players. The conducted studies show that the number and times of meals affect physical performance. It was determined that athletes with five meals performed better than those who ate three meals and total working efficiency increased with five meals (31). Öztürk (29) reported that all professional footballers had a feeding habit 3-4 hours before the competition and $95 \%$ of amateur 2 - 3 hours before the competitions. The athlete must take part in the competition digesting what he has eaten. Being hungry or full affects the performance negatively (31). In the study conducted by Sanlier and Arikan (38), $49.8 \%$ of athletes consumed meals three times a day, $28.4 \%$ four times, $14 \%$ twice a day, $7.8 \%$ five or more meals a day. In their study, Sağlam (32) found that $84.6 \%$ of football players consumed 3 meals a day, $12.5 \%$ consumed four meals and more. The fact that $68 \%$ of professional football players participating in our research, $44 \%$ of amateurs and $56 \%$ of all football players said that they ate the last meal before the competition 3-4 hours ago, can be considered as having sufficient information about this subject.

Consequently, the clubs, trainers and athletes looking for success on a national level and international platform should cooperate with a nutritionist. In the domestic and foreign literature, it is revealed that nutrition information and habits of amateur and professional football players, which are the subject of our study parallel to the studies on nutrition habits of athletes, are not in good condition; and nutritional problems are existed.

In the light of nutritional information supported by scientific studies, we believe that it is very beneficial to support athletes and trainers with nutrition training, seminars, courses, panel etc., make a specialized nutritionist in the sports clubs available and constantly emphasize the importance of this issue in the written and visual media.

\section{REFERENCES}

1. Abood DA, Black DR, Birnbaum RD. Nutrition education intervention for college female athletes. Journal of nutrition education and behavior. 2004; 36(3): 135-139.

2. Akıl C. Dayanıklılık sporcularında beslenme bilgi düzeylerinin belirlenmesi (Doctoral dissertation, Selçuk Üniversitesi Sağlık Bilimleri Enstitüsü). 2007.

3. Alpar R, Ersoy G, Karagül A. Yüzücü beslenmesi el kitabı. GSGM Yayın. 1994; (127), 69-84. 
4. Arıkan B, Şanlıer N. Amatör Tenisçilerin Beslenme Durumlarının ve Bazı Antropometrik Ölçümlerinin Saptanması. 9. Uluslararası Spor Bilimleri Kongresi. 2006; 428-431.

5. Atamtürk H, Ahmedov S, Tokmak H. P-074 Lifestyles and nutritional habits of footballers from North Cyprus Football League. Journal of Sports Science and Medicine. 2007; 10.

6. Atay E, Kılınç F, Çetinkaya E, Kılıç T. Türkiye yarı finallerine katılan yıldızlar kategorisi ilköğretim okulları futbolcularının beslenme alışkanlık düzeylerinin incelenmesi. 9. Uluslararası Spor Bilimleri Kongresi, Bildiri Kitapçı̆̆ı. 2006; 475-477.

7. Ayça B, Çiloğlu F. Futbolcuların performans arttırmak amacıyla kullandıkları ilaçlar ve besin tamamlayıcıları. VI. Ulusal Spor Hekimliği Kongresi. 1997.

8. Başoğlu S. Sporcu beslenmesi, doping ve futbolda performans artırma yöntemleri". Form Reklam Hizmetleri, İstanbul. 2004.

9. Bayrakdar A, Saygın Ö, Karacabey K, Gelen E. Üniversite öğrencilerinin beslenme bilgi ve alışkanlıklarının incelenmesi 1. Adli Bilimler ve Spor Kongresi, Bildiri Kitapçı̆̆ı. 2008; 45.

10. Bayraktar I, Yaman Ç. Olimpik Branş Antrenörlerinin Beslenme Tutumlarının Araştırılması. Türkiye Sosyal Araştırmalar Dergisi. 2002. 6(3), 144-161.

11. Baysal A. Beslenme (9. baskı). Hatiboğlu Yayınları, Ankara (2002).

12. Bilgiç C, Bilgiç P, Ersoy G. Akdeniz oyunlarına katılan türk sporcuların beslenme bilgi ve uygulamalarının değerlendirilmesi. 7. Spor Bilimleri Kongresi. 2001; 171.

13. Bozkurt İ. Beden Eğitimi ve Spor Yüksek Okullarında Aktif Spor Yapan Öğrencilerin Beslenme Alışkanlıklarının Belirlenmesi ve Değerlendirilmesi. (Yüksek Lisans Tezi). Selçuk Üniversitesi Sağlık Bilimleri Enstitüsü. 2001.

14. Bulduk S. Beslenme ilkeleri ve mönü planlama. Detay Yayıncilık. Ankara. 2013; 11.

15. Douglas PD, Douglas JG. Nutrition knowledge and food practices of high school athletes. Journal of the American Dietetic Association. 1984; 84(10), 1198-1202.

16. Dündar U. Antrenman teorisi. Bağırgan Yayınevi, 3. Bask1, Ankara. 1996; 66.

17. Ersoy G. Sağlıklı yaşam, spor ve beslenme. Damla Matbaacılık, Ankara. 1995.

18. Göral K, Çevik H, Saygın Ö, Öcal K. Amatör Futbolcuların Beslenme Alışkanlıklarının Değerlendirilmesi, 9. Uluslararası Spor Bilimleri Kongresi, Bildiri Kitapçı̆̆ı. 2006; 548.

19. Güler D, Şenel Ö, Çolak M, Dönmez G, Zorba E. Bazı Takım Sporlarındaki Üst Düzey Sporcuların Ergojenik Yardımcılar Hakkındaki Bilgi ve Kullanım Düzeyleri. In The 10th Ichper SD Europe Congress \& 8th International Sport Science Congress. 2004; 134.

20. Günay M. Spor fizyolojisi. Gazi Kitabevi. 2001.

21. Güneş Z. Spor ve beslenme. Ankara: Nobel Yayın Dağıtım. 2005.

22. Gürsoy R, Aktaş Ö, Dane Ş. Beslenme ve Besinsel Ergojenikler I: Karbonhidrat, Yag Ve Proteinler. Beden Eğitimi ve Spor Bilimleri Dergis. 2001; 1(2).
23. Hickner RC, Fisher JS, Hansen PA, Racette SB, Mier CM, Turner MJ, Holloszy JO. Muscle glycogen accumulation after endurance exercise in trained and untrained individuals. Journal of Applied Physiology. 1997; 83(3), 897903.

24. Javandel H, Berahmandpour F. Nutrition behavior, body activity and health interactions: $\mathrm{Pb}$ 85. Tropical Medicine \& International Health. 2007; 12, 229.

25. Leblanc JC, Gall FL, Grandjean V, Verger P. Nutritional intake of French soccer players at the Clairefontaine training center. International journal of sport nutrition and exercise metabolism. 2002; 12(3), 268-280.

26. Massad SJ, Shier NW, Koceja DM, Ellis NT. High school athletes and nutritional supplements: a study of knowledge and use. International Journal of Sport Nutrition. 1995; 5(3), 232-245

27. Maughan R. Sports nutrition: an overview. Hospital medicine. 2002; 63(3), 136-139.

28. Özmerdivenli R, Karacabey K. Sporcularda yolculukta ve müsabakalarda sıvı alınımı ve beslenme. Beden Egitimi ve Spor Bilimleri Dergisi. 2002; 4(2), 28-32.

29. Öztürk A. Profesyonel ve Amatör Futbolcuların Beslenme Alışkanlıkları ve Vücut Bileşimleri. Cumhuriyet Üniversitesi, Sosyal Bilimler Enstitüsü, Beden Eğitimi ve Spor Anabilim Dalı, Yüksek Lisans Tezi, Sivas. 2006.

30. Paker HS. Besinlerin Yenebilen 100 gramlarının Enerji ve Besin Öğeleri Değerleri. Sporda Beslenme, Gen Matbaacilık ve Reklamcilık, Ankara. 1996.

31. Pulur A, Cicioğlu İ. Nutritional knowledge and habits of female basketball players. Atatürk University Journal of Physical Education and Sports. 2001; 1(2), 44-49.

32. Sağlam F. Futbolcuların Beslenme Alışkanlıkları. Spor Bilimleri Dergisi. 1993; 4(2), 27-34.

33. Sevim Y. Antrenman bilgisi. Nobel Yayın Dağıtım. 2007.

34. Sivrikaya AH. Atatürk Üniversitesi beden eğitimi ve spor yüksek okulu voleybol takımı sporcularının sporcu beslenmesine ilişkin bilgi düzeylerinin incelenmesi. 9. Uluslararası Spor Bilimleri Kongresi. 2006; 554-555.

35. Süel E, Şahin İ, Karakaya MA, Savucu Y. Elit seviyedeki basketbolcuların beslenme bilgi ve alışkanlıkları. Fırat Üniversitesi Sağlık Bilimleri Tıp Dergisi. 2006; 20(4), 271-275.

36. Sürücüoğlu MS, Özçelik AÖ, Çakıroğlu FP. Yüzücülerin beslenme alışkanlıkları ve bilgi düzeyleri. Performans Dergisi. 1996; 2, 11-15.

37. Swirzınskı L, Latın RW, Berg K, Grandjean A. A Survey Of Sport nutrition supplements in high school football players. The Journal of Strength \& Conditioning Research. 2000; 14(4), 464-469.

38. Şanlıer N, Arıkan B. Ankara'da Çeşitli Üniversitelerde Beden Eğitimi ve Spor Yüksek Okullarına Devam Eden Son Sınıf Öğrencilerin Beslenme ve Ek Ergojenik Yardımcıları Kullanma Durumlarının Saptanması. 1. Gazi Üniversitesi Beden Eğitimi ve Spor Bilimleri Kongresi. 2000; 26-27.

39. Şenel Ö, Güler D, İsmail KA, Ersoy A, Kürkçü R. Farklı Ferdi Branşlardaki Üst Düzey Türk Sporcuların Ergojenik Yardımcılara Yönelik Bilgi ve Yararlanma 
Düzeyleri. Spormetre Beden Eğitimi ve Spor Bilimleri Dergisi. 2004; 2(2), 41-47.

40. Yıldıran İ, Bayraktar I. Antrenörlerin Beslenme Bilgi ve Alışkanlıkları. Hacettepe Üniversitesi Atletizm Bilim ve Teknolojisi Dergisi. 2000; (40).
41. Zinn C, Schofield G, Wall C. Evaluation of sports nutrition knowledge of New Zealand premier club rugby coaches. International Journal of Sport Nutrition and Exercise Metabolism, 2006; 16(2), 214-225. 